\title{
ANALISIS HUBUNGAN KONSTITUTIF PADA BATUAN ANISOTROP
}

\author{
Analysis of Constitutive Behaviour on Anisotropic Rock
}

\author{
INDRA K. WIJAKSANA \\ Prodi Teknik Pertambangan, Universitas Islam Bandung \\ Jl. Tamansari No. 1 Bandung 40116 \\ e-mail: indra k wijaksana@yahoo.com
}

\begin{abstract}
ABSTRAK
Banyak batuan yang tersingkap di permukaan bumi mempunyai struktur dasar dalam bentuk perlapisan, foliasi, fissure, ataupun joint. Secara umum, batuan memiliki sifat (fisik, dinamik, thermal, mekanik, dan hidrolik) yang berbeda sesuai dengan arahnya dan disebut sebagai sifat anisotrop. Pemahaman akan sifat-sifat mekanik dari batuan anisotrop, dapat membantu memprediksi perilaku batuan dalam desain, analisis, dan konstruksi, juga memperbaiki kualitas dan keamanan. Pada penelitian ini dibahas mengenai metode pengujian laboratorium dan analitik untuk menentukan keempat nilai konstanta elastik batu slate yang bersifat isotrop transverse. Perhitungan analitik dilakukan untuk menentukan konstanta elastik dari material batuan dengan asumsi linier, elastik, homogen, dan isotrop transverse. Nilai regangan ditentukan pada kondisi $50 \%$ dari tegangan puncak pada kurva tegangan-regangan. Analisis multilinier regresi dengan metode estimasi kuadrat terkecil digunakan dalam menentukan persamaan linier untuk mendapatkan keempat konstanta elastik dari batuan. Pada penelitian ini, batuan yang digunakan sebagai contoh dalam uji laboratorium diperoleh dari dua buah blok batu slate yang berasal dari sungai Bora, daerah Palu Sulawesi Tengah. Batuan-batuan ini memiliki arah foliasi yang nampak pada permukaannya, dan oleh karena itu batuan ini akan diperlakukan sebagai material isotrop transverse. Dari hasil uji kuat tekan uniaksial, diketahui bahwa batu slate tersebut mempunyai kemampuan deformasi yang lebih besar pada arah normal terhadap bidang isotrop transversenya $\left(\theta=85^{\circ}\right)$, daripada kemampuan deformasi pada arah sejajar dengan bidang isotrop transversenya $\left(\theta=5^{\circ}\right)$.
\end{abstract}

Kata kunci: batuan isotrop transverse, konstanta elastik, uji kuat tekan uniaksial

\begin{abstract}
Many exposed rocks show well-defined fabric elements in the form of bedding, stratification, layering, foliation, fissure, or joint. In general, these rocks have properties (physical, dynamic, thermal, mechanical, and hydraulic) that vary with direction and are said to be inherently anisotropic. Evaluating anisotropic mechanical properties helps to predict the behavior of rock materials in analysis, design, and construction, and improves the quality and safety. This research discussed laboratory testing and analytical methods to determine the four values of elastic constants of transversely isotropic slate rock. Analytic calculations were performed to determine the elastic constants of rock material with the assumption of linear, elastic, homogeneous, and transversely isotropic. The strain value was determined at of $50 \%$ of peak stress on stress-strain curves. Multilinear regression analysis with least squares estimation method was used in determining the linear equation to get to the four elastic constants of the rock. In this study, the rock used as an example in laboratory tests obtained from two pieces of slate stone blocks from the Bora river, Central Sulawesi Palu area. These rocks have foliation that appears on the surface, and therefore these rocks will be treated as a transversely isotropic material. The results of uniaxial compression tests revealed that for the slate rock, the deformability in the direction that is normal to the plane of transverse isotropy $\left(\theta=85^{\circ}\right)$ is greater than that is parallel to the plane of transverse isotropy $\left(\theta=5^{\circ}\right)$ or, in other words, $E_{1}>E_{2}$.
\end{abstract}

Keywords: transversely isotropic rock, elastic constants, uniaxial test 


\section{PENDAHULUAN}

Banyak batuan yang tersingkap di permukaan bumi mempunyai struktur dasar dalam bentuk perlapisan, foliasi, fissure, ataupun joint (Ismael dkk., 2014). Secara umum, batuan memiliki sifat (fisik, dinamik, thermal, mekanik, dan hidrolik) yang berbeda sesuai dengan arahnya dan ini yang disebut sebagai sifat anisotrop (Kim dkk., 2012; Min dkk., 2015). Mengetahui sifat-sifat mekanik dari batuan anisotrop, dapat membantu memprediksi perilaku batuan dalam desain, analisis, dan konstruksi, juga memperbaiki kualitas dan keamanan. Konstanta elastik dari batuan anisotrop juga mempengaruhi analisis deformasi dan desain (Bidgoli dan Jing, 2014). Oleh karena itu, sangat penting untuk dapat memperkirakan konstanta elastik dari batuan anisotrop dengan cepat dan akurat.

Di dalam analisis dan penelitian, material anisotrop disederhanakan menjadi orthotrop dan isotrop transverse (Wang dkk., 2011). Dalam analisis batuan isotrop transverse sebenarnya ada lima konstanta elastik yang diperlukan dalam perhitungan yaitu : modulus Young $E_{1}$ dan Poisson rasio $v_{1}$ dari bidang isotrop transverse, juga modulus Young $\mathrm{E}_{2}$, Poisson rasio $v_{2}$ dan modulus geser $G_{2}$ dari arah normal terhadap bidang isotrop transverse, namun di dalam penelitian ini hanya ada empat konstanta elastik yang bisa diperoleh yaitu $E_{1}, v_{1}, E_{2}$, dan $v_{2}$. Nilai modulus geser $\mathrm{G}_{2}$ tidak bisa diperoleh dalam perhitungan dikarenakan keterbatasan pada alat ukur regangan yang dipergunakan dalam uji laboratorium. Ada beberapa metode yang dapat digunakan untuk menentukan konstanta elastik dari batuan anisotrop, termasuk di dalamnya uji in situ, tes laboratorium dan metode analisis numerik (Wang dkk., 2011; Bidgoli dan Jing, 2014; Min dkk., 2015). Uji laboratorium dapat dibedakan menjadi uji dengan metode dinamik dan statik. Metode dinamik termasuk metode resonant bar dan metode ultrasonic pulse. Metode statik termasuk uniaxial compression test, conventional triaxial compression test, true triaxial compression test, hollow cylinder test, bending test, torsion test, dan diametral compression test (Brazilian test) (Rai dkk., 2014; Vervoort $d k k ., 2014)$.

Konstanta elastik dari batuan anisotrop dapat dihitung dengan mensubstitusikan gaya pembebanan dan data regangan yang tercatat dalam percobaan ke dalam persamaan tegangan-regangan. Untuk menentukan lima buah konstanta elastik bebas pada batuan isotrop transverse, Kim dkk. (2012) membuat contoh berbentuk silinder dengan satu arah pembebanan diperlukan dalam pengujian dengan uniaxial compression test. Pada penelitian ini, telah digunakan kombinasi metode eksperimentasi dan analitik untuk menentukan empat konstanta elastik dari batuan isotrop transverse di laboratorium.

\section{METODE}

\section{Persamaan Konstitutif pada Uji Kuat Tekan Uniaksial}

Pada penelitian ini nilai konstanta elastik yang terdapat dalam material isotrop transverse, ditentukan oleh hubungan konstitutif melalui hukum Hooke (Min dkk., 2015). Salah satu contoh dari material isotrop transverse antara lain adalah adanya bidang perlapisan (Wang $d k k ., 2013)$. Bidang perlapisan ini dapat mempunyai variasi kemiringan yang berbedabeda, mulai dari sejajar hingga tegak lurus terhadap bidang datarnya. Dengan kondisi tersebut, batuan akan memiliki respon yang berbeda-beda pada saat menerima tegangan (Vervoort $d k k ., 2014)$.

Salah satu metode uji laboratorium untuk menentukan konstanta elastik dari batuan adalah uji kuat tekan uniaksial (Gao $d k k_{\text {., }}$ 2015). Di dalam uji kuat tekan uniaksial, contoh hanya menerima tegangan pada arah sumbu utamanya saja. Oleh karena itu, tegangan pada kedua sumbu lainnya sama dengan nol. Sumbu z dianggap sebagai sumbu utama yang tegak lurus terhadap bidang isotrop transverse, sedangkan sumbu $\mathrm{x}$ dan y adalah sumbu yang sejajar dengan bidang isotrop transverse. Untuk mendapatkan persamaan konstitutif pada material isotrop transverse digunakan persamaan (1b): 


$$
\left[\begin{array}{l}
\varepsilon_{x} \\
\varepsilon_{y} \\
\varepsilon_{z} \\
\gamma_{x y} \\
\gamma_{y z} \\
\gamma_{z x}
\end{array}\right]=\left[\begin{array}{cccccc}
\frac{1}{E_{x}} & \frac{-v_{x y}}{E_{y}} & \frac{-v_{x z}}{E_{z}} & 0 & 0 & 0 \\
\frac{-v_{y x}}{E_{x}} & \frac{1}{E_{y}} & \frac{-v_{y z}}{E_{z}} & 0 & 0 & 0 \\
\frac{-v_{z x}}{E_{x}} & \frac{-v_{z y}}{E_{y}} & \frac{1}{E_{z}} & 0 & 0 & 0 \\
0 & 0 & 0 & \frac{1}{G_{x y}} & 0 & 0 \\
0 & 0 & 0 & 0 & \frac{1}{G_{y z}} & 0 \\
0 & 0 & 0 & 0 & 0 & \frac{1}{G_{z x}}
\end{array}\right]\left[\begin{array}{c}
\sigma_{x} \\
\sigma_{y} \\
\sigma_{z} \\
\tau_{x y} \\
\tau_{y z} \\
\tau_{x z}
\end{array}\right]
$$

sedangkan sumbu z nya merupakan sumbu simetri elastik rotasi.

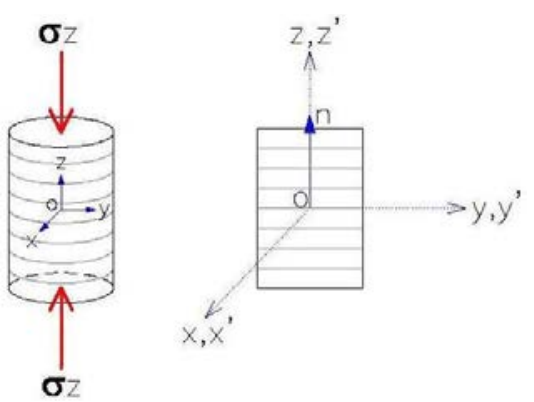

Gambar 1. Material isotrop transverse dengan sumbu simetri elastik rotasi z pada saat $\theta=0^{\circ}$ (Raidkk., 2014)

Pada persamaan (1b), diasumsikan bahwa sudut yang dibentuk oleh bidang perlapisan terhadap bidang datarnya sama dengan nol, $\theta$ $=0^{\circ}$ (Gambar 1). Oleh karena itu, tidak akan terdapat fungsi dari sudut $\theta$ dalam persamaan konstitutifnya. Pada saat bidang perlapisan tersebut membentuk sudut kemiringan tertentu terhadap bidang horizontalnya (Gambar 2), maka konstanta elastik yang diperoleh dari koordinat global ditransformasikan ke dalam koordinat lokalnya.

Karena pada uji kuat tekan uniaksial $\sigma_{x}=\sigma_{y}$ $=0$, maka nilai persamaan matrix yang sebenarnya dicari adalah (Rai dkk., 2014):

$$
\left\{\begin{array}{l}
\mathcal{E}_{x} \\
\hdashline \varepsilon_{y} \\
\hdashline \varepsilon_{z} \\
\hdashline \gamma_{x y} \\
\gamma_{y z} \\
\gamma_{z x}
\end{array}\right]=\left[\begin{array}{llll:ll}
A_{11} & A_{12} & A_{13} & A_{14} ; & A_{15} & A_{16} \\
A_{21} & A_{22} & A_{23} & A_{24} & A_{25} & A_{26} \\
A_{31} & A_{32} & A_{33} & A_{34} & A_{35} & A_{36} \\
A_{41} & A_{42} & A_{43} & A_{44}^{-} & A_{45} & A_{46} \\
A_{51} & A_{52} & A_{53} & A_{54} & A_{55} & A_{56} \\
A_{61} & A_{62} & A_{63} & A_{64} & A_{65} & A_{66}
\end{array}\right]\left[\begin{array}{c}
\sigma_{x} \\
\sigma_{y} \\
\hdashline \sigma_{z} \\
\hdashline \tau_{x y} \\
\tau_{y z} \\
\tau_{z x}
\end{array}\right],
$$

Matrix compliance [A] di atas kemudian ditransformasikan ke dalam koordinat lokalnya dengan persamaan (3). Sehingga diperoleh nilai konstanta elastik ketika bidang perlapisannya memiliki kemiringan yang bervariasi terhadap bidang datarnya.

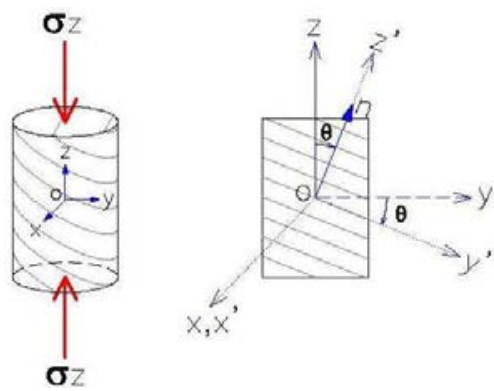

Gambar 2. Material isotrop transverse dengan sumbu simetri elastik rotasi $z$ pada saat $\theta \neq 0^{\circ}$ (Rai dkk., 2013)

\section{Uji Kuat Tekan Uniaksial}

Batu slate dipilih sebagai batuan yang digunakan dalam penelitian. Karena batuan ini memiliki arah foliasi yang nampak pada permukaannya, maka batuan ini dikategorikan sebagai material isotrop transverse (Wang dkk., 2011). Untuk mendapatkan contoh dengan sudut $\theta$ yang bervariasi, dua buah blok batu slate dicoring dengan diameter core bit yang digunakan adalah $45 \mathrm{~mm}$. Selanjutnya blok batuan tersebut diletakkan di bawah mesin inti bor (core drill) dengan arah kemiringan terhadap bidang perlapisan yang telah ditentukan sebelumnya. Pada blok batuan yang pertama, didapatkan contoh hasil coring dengan kemiringan yang relatif datar dan tegak terhadap bidang horizontalnya. Sedangkan pada blok batuan yang kedua, didapatkan contoh dengan kemiringan bervariasi antara $35^{\circ}$ hingga $75^{\circ}$ terhadap bidang horizontalnya. Siraman air diberikan untuk membantu mempermudah proses coring.

Pada Gambar 4 dan 5 diperlihatkan variasi nilai UCS dan modulus elastisitas terhadap sudut $\theta$ hasil dari uji kuat tekan uniaksial di laboratorium. Nilai modulus elastisitas dihitung dari porsi linier pada kurva teganganregangan (Bidgoli dan Jing, 2014), sehingga diperoleh nilai modulus elastisitas rataratanya. 


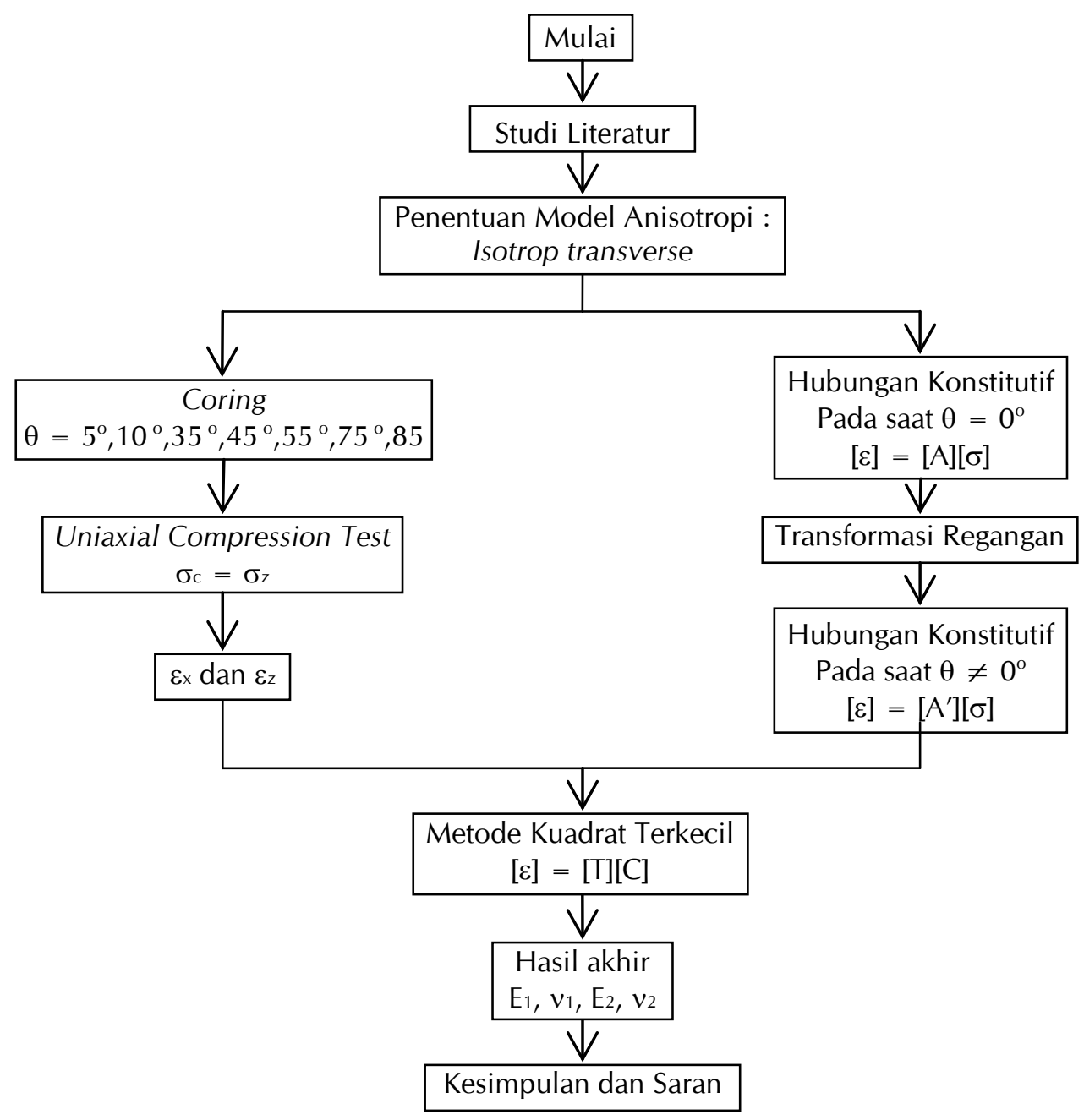

Gambar 3. Diagram alir metodologi penelitian

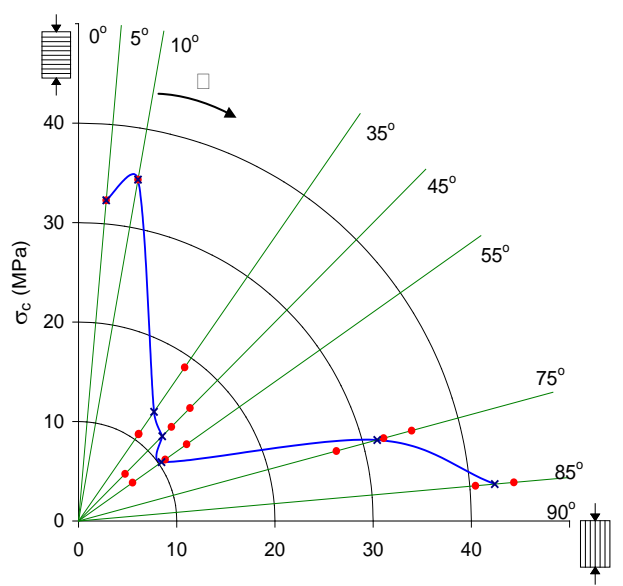

Gambar 4. Variasi dari uniaxial compressive strength terhadap sudut $\theta$

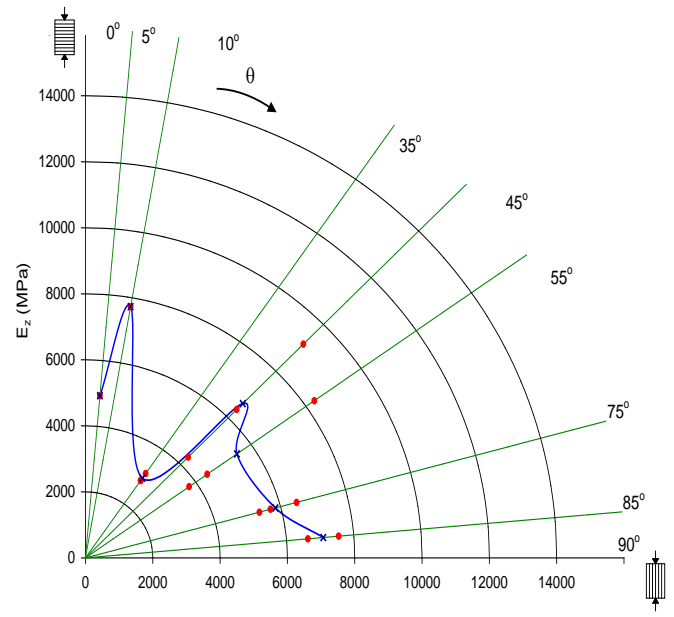

Gambar 5. Variasi dari modulus elastisitas terhadap sudut $\theta$ 


\section{HASIL DAN PEMBAHASAN}

\section{Transformasi Matrix Compliance}

Dari Gambar 1 dan 2 di atas dapat dilihat bahwa sumbu $x$ dan $y$ terletak dalam satu bidang simetri elastik $x, y$. Ini berarti seluruh sifat mekanik yang terdapat pada arah $\mathrm{x}$ akan mempunyai sifat yang serupa dengan yang dimiliki oleh arah y. Dengan demikian, maka konstanta elastiknya berkurang dari 9 pada persamaan (1b) menjadi 5 buah pada persamaan (2)

$[\varepsilon]=[A][\sigma]$

atau dalam bentuk umumnya (Wang $d k k$., 2013; Rai dkk., 2014; Min dkk., 2015):

$\left[\begin{array}{l}\varepsilon_{x} \\ \varepsilon_{y} \\ \varepsilon_{z} \\ \gamma_{x y} \\ \gamma_{y z} \\ \gamma_{z x}\end{array}\right]=\left[\begin{array}{cccccc}\frac{1}{E_{x}} & \frac{-v_{x y}}{E_{y}} & \frac{-v_{x z}}{E_{z}} & 0 & 0 & 0 \\ \frac{-v_{y x}}{E_{x}} & \frac{1}{E_{y}} & \frac{-v_{y z}}{E_{z}} & 0 & 0 & 0 \\ \frac{-v_{z x}}{E_{x}} & \frac{-v_{z y}}{E_{y}} & \frac{1}{E_{z}} & 0 & 0 & 0 \\ 0 & 0 & 0 & \frac{1}{G_{x y}} & 0 & 0 \\ 0 & 0 & 0 & 0 & \frac{1}{G_{y z}} & 0 \\ 0 & 0 & 0 & 0 & 0 & \frac{1}{G_{z x}}\end{array}\right]\left[\begin{array}{c}\sigma_{x} \\ \sigma_{y} \\ \sigma_{z} \\ \tau_{x y} \\ \tau_{y z} \\ \tau_{x z}\end{array}\right]_{(1 b)}$

Persamaan konstitutif untuk material isotrop transverse akan disederhanakan dengan adanya asumsi seperti persamaan (2) berikut:

$\mathrm{Ex}_{\mathrm{x}}=\mathrm{E}_{\mathrm{y}}=\mathrm{E}$

$\mathrm{E}_{z}=\mathrm{E}_{2}$

$v_{x y}=v_{y x}=v_{1}$

$v_{z x}=v_{z y}=v_{2}$

$\mathrm{G}_{\mathrm{zx}}=\mathrm{G}_{\mathrm{zy}}=\mathrm{G}_{2}$

Berikut ini adalah langkah-langkah untuk mentransformasi matrix compliance [A] dari koordinat global ( $x$ y $z$ ) ke dalam koordinat lokalnya $\left(x^{\prime} y^{\prime} z^{\prime}\right)$, sesuai dengan persamaan (3) berikut (Rai dkk., 2014)

$\left[\mathrm{A}^{\prime}\right]=[\mathrm{P}][\mathrm{A}][\mathrm{P}]^{\top}$

Sehingga dari persamaan di atas dapat diperoleh komponen persamaan matrix $\left[\mathrm{A}^{\prime}\right]$ yang merupakan hasil transformasi matrix compliance [A] dari koordinat global ke dalam koordinat lokalnya seperti persamaan berikut:

$$
\begin{aligned}
& A_{13}=-\frac{v_{1}}{E_{1}} \sin ^{2} \theta-\frac{v_{2}}{E_{2}} \cos ^{2} \theta \\
& A_{23}=\frac{\sin ^{2} 2 \theta}{4}\left(\frac{1}{E_{1}}+\frac{1}{E_{2}}\right)-\frac{v_{2}}{E_{2}}\left(\sin ^{4} \theta+\cos ^{4} \theta\right) \\
& A_{33}=\frac{\sin ^{4} \theta}{E_{1}}+\frac{\cos ^{4} \theta}{E_{2}}-\frac{v_{2} \sin ^{2} 2 \theta}{2 E_{2}}
\end{aligned}
$$

Pada akhirnya akan diperoleh persamaan konstitutif yang telah disederhanakan (persamaan 5), hasil dari transformasi regangan dari koordinat global ke dalam koordinat lokalnya.

$$
\left[\begin{array}{c}
\varepsilon_{x} \\
\varepsilon_{y} \\
\varepsilon_{z}
\end{array}\right]=\left[\begin{array}{c}
A_{13}^{\prime} \\
A_{23}^{\prime} \\
A_{33}^{\prime}
\end{array}\right] \cdot \sigma_{z}
$$

\section{Perhitungan Matrix Compliance}

Seluruh pengukuran regangan dianalisis secara simultan. Misalkan $\mathrm{n}$ adalah dari seluruh pengukuran regangan (dimana $n \geq 4$ ) untuk ke enam belas contoh yang diuji. Sesuai dengan persamaan (4) dan (5) bahwa setiap pengukuran regangan berhubungan linier terhadap keempat komponen compliance

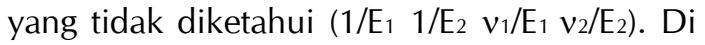
dalam bentuk matrix, pengukuran regangan dapat ditunjukkan dalam kaitannya dengan ke empat buah compliancenya sebagai berikut:

$[\varepsilon]=[\mathrm{T}][\mathrm{C}]$

$[\varepsilon]=$ matrix $(\mathrm{n} \times 1)$ dari pengukuran regangan, $n$ adalah jumlah total pengukuran $(n>4)$

$[T]=$ matrix $(n \times 4)$ yang berhubungan dengan sudut $\theta$

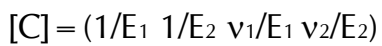

$[\varepsilon]=[T] \cdot\left[\begin{array}{c}\frac{1}{E_{1}} \\ \frac{1}{E_{2}} \\ \frac{v_{1}}{E_{1}} \\ \frac{v_{2}}{E_{2}}\end{array}\right]$ 
Persamaan (6b) kemudian diselesaikan dengan estimasi kuadrat terkecil untuk ke empat nilai compliance dengan analisis multilinier regresi (Cheng dkk., 2015). Keuntungan dari pendekatan ini adalah semua pengukuran regangan dimasukkan ke dalam perhitungan ketika menentukan nilai compliancenya. Selain itu, metode ini dapat dikembangkan untuk contoh dalam jumlah yang cukup banyak.

Karena pada pengujian tidak dilakukan pengukuran deformasi pada arah $y$, maka persamaan matrix compliance untuk $\varepsilon_{y}$ tidak dimasukan dalam analisis. Sebagai contoh ilustrasi pada contoh no. 1

$\theta=85^{\circ}$

$\sigma_{c}=40,58 \mathrm{MPa} \Rightarrow 50 \% . \sigma_{c}=20,29 \mathrm{MPa}$

Dalam perhitungan matrix data yang dimasukan adalah sebagai berikut:

$\left[\begin{array}{l}\varepsilon_{x} \\ \varepsilon_{z}\end{array}\right]=\left[\begin{array}{cccc}0 & 0 & -\sigma_{c} \sin ^{2} \theta & -\sigma_{c} \cos ^{2} \theta \\ \sigma_{c} \sin ^{4} \theta & \sigma_{c} \cos ^{4} \theta & 0 & -\frac{\sigma_{c} \sin ^{2} 2 \theta}{2}\end{array}\right]\left[\begin{array}{c}\frac{1}{E_{1}} \\ \frac{1}{E_{2}} \\ \frac{v_{1}}{E_{1}} \\ \frac{v_{2}}{E_{2}}\end{array}\right]$

Substitusikan data tersebut ke dalam persamaan (6b), maka akan diperoleh

$\left[\begin{array}{r}-0.001170 \\ 0.003490\end{array}\right]=\left[\begin{array}{rrrr}0 & 0 & -20.135415 & -0.154122 \\ 19.982464 & 0.001171 & 0 & -0.305902\end{array}\right]\left[\begin{array}{c}1 / \mathrm{E}_{1} \\ 1 / \mathrm{E}_{2} \\ \mathrm{v}_{1} / \mathrm{E}_{1} \\ \mathrm{v}_{2} / \mathrm{E}_{2}\end{array}\right]$

Metode yang dijelaskan di atas digunakan pada keenam belas contoh batu slate, dalam uji kuat tekan uniaksial. Regangan yang digunakan dalam analisis seluruhnya ditentukan pada $50 \%$ dari tegangan puncak.

\section{Perhitungan Konstanta Elastik dengan Multi Linier Regresi}

Dari data di atas diketahui $n=32$ buah pengamatan dan $k=4$ buah variabel. Dengan menghilangkan asumsi bo maka persamaan multi linier regresinya adalah (Cheng $d k k$., 2015):

$y_{i}=b_{1} x_{1 i}+b_{2} x_{2 i}+b_{3} x_{3 i}+b_{4} x_{4 i}+e_{i}$

Konsep dari kuadrat terkecil digunakan untuk memperoleh estimasi $b_{1}, b_{2}, b_{3}$ dan $b_{4}$. Dengan menurunkan jumlah kuadrat kesalahan terhadap masing-masing koefisien $b_{1}, b_{2}, b_{3}, b_{4}$ dan hasilnya sama dengan nol, maka akan diperoleh persamaan normal dalam bentuk matrix $\mathrm{Ab}=\mathrm{g}$

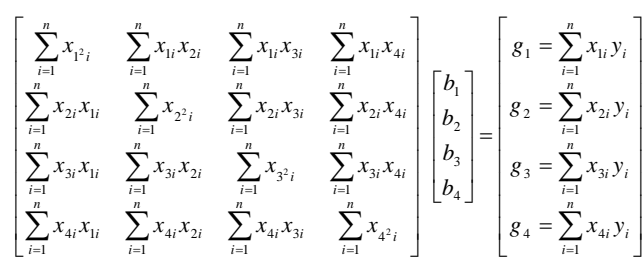

Hasil analisis dari ke 32 pengukuran regangan $(n=32)$ menghasilkan konstanta elastik di bawah ini:

$b_{1}=\frac{1}{E_{1}}=0,000199 \quad \Rightarrow \quad E_{1}=5028,995 \quad M P a$

$b_{2}=\frac{1}{E_{2}}=0,000234 \Rightarrow E_{2}=4274,661 \quad M P a$

$b_{3}=\frac{v_{1}}{E_{1}}=0,000060 \Rightarrow v_{1}=0,302$

$b_{4}=\frac{v_{2}}{E_{2}}=0,000025 \Rightarrow v_{2}=0,106$

Nilai $E_{1} / E_{2}=1,176$ artinya pada batuan tersebut, kemampuan deformasi pada arah normal terhadap bidang perlapisannya lebih besar daripada kemampuan deformasi pada arah sejajar dengan perlapisannya.

Gambar 6 menyajikan grafik perbandingan antara tegangan - regangan hasil uji laboratorium terhadap hasil model persamaan pada contoh no.1. 


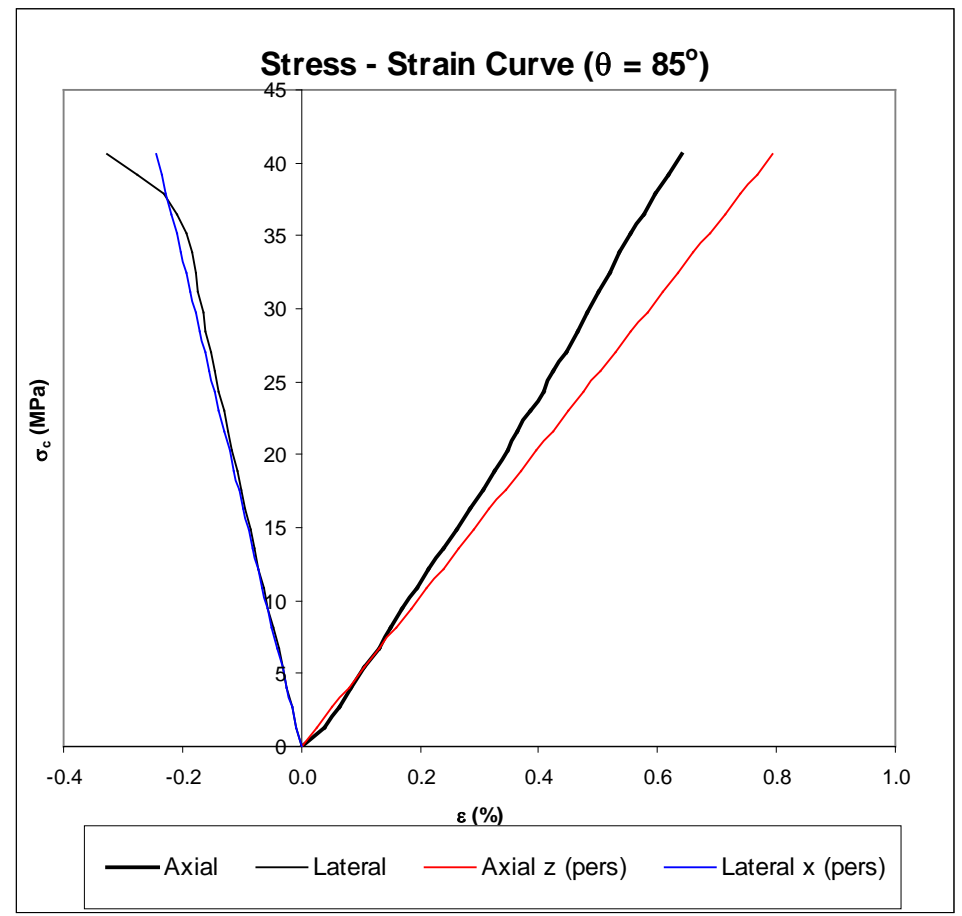

Gambar 6. Grafik tegangan dan regangan perbandingan hasil uji laboratorium - model

\section{KESIMPULAN DAN SARAN}

\section{Kesimpulan}

Material batuan diasumsikan linier, elastik, homogen, kontinu dan isotrop transverse. Batu slate yang merupakan batuan berfoliasi dengan arah foliasi yang nampak pada permukaannya diperlakukan sebagai material isotrop transverse. Di dalam uji kuat tekan uniaksial, kemiringan bidang foliasi terhadap bidang datar dibuat bervariasi mulai dari $5^{\circ}$ $85^{\circ}$ dari bidang datarnya.

Alat ukur yang digunakan dalam mengukur besarnya deformasi yang terjadi pada batuan adalah dial gauge. Dial gauge bekerja berdasarkan indikasi tekanan yang terjadi pada spindle sebagai akibat dari adanya perubahan bentuk pada permukaan batuan, yang akan memutarkan bacaan tertentu pada skala penghitung putarannya sebagai nilai deformasi yang terjadi pada batuan tersebut, karena itu di dalam proses perolehan data, nilai deformasi yang diperlukan untuk menghitung besarnya modulus geser $\mathrm{G}_{2}$ tidak dapat diperoleh. Sebaiknya alat ukur yang digunakan adalah strain gauge, yang mampu mengukur besarnya regangan yang terjadi berdasarkan prinsip rasio perubahan panjang terhadap panjang semula. Karena itu, nilai regangan dalam dua arah koordinat yang berbeda dapat sekaligus terukur untuk mendapatkan nilai modulus $\mathrm{G}_{2}$ dari batuan.

Variasi nilai UCS terhadap sudut $\theta$ menunjukkan nilai kuat tekan maksimum muncul pada saat gaya diberikan pada arah sejajar terhadap bidang isotropi $\left(\theta=85^{\circ}\right)$. Dari nilai regangan yang diukur pada kondisi $50 \%$ dari tegangan puncak pada kurva tegangan-regangan, nilai konstanta elastik ditentukan. Penghitungan konstanta elastik secant dengan estimasi kuadrat terkecil, sebanyak jumlah pengujian $(n=32)$ dan diperoleh nilai $\mathrm{E}_{1}=5028,995 \mathrm{MPa}, \mathrm{E}_{2}=$ 4274,661 MPa, $v_{1}=0,302$ dan $v_{2}=0,106$. Nilai $E_{1} / E_{2}=1,176$ yang menandakan bahwa untuk batuan tersebut, kemampuan deformasi pada arah normal terhadap bidang perlapisannya lebih besar daripada kemampuan deformasi pada arah sejajar dengan perlapisannya. 


\section{Saran}

Dari hasil yang diperoleh dalam penelitian ini, ada beberapa hal yang masih menjadi keterbatasan di dalam penelitian ini yang dapat dikembangkan untuk penelitian yang akan datang, yaitu pengukuran regangan lateral dalam uji kuat tekan uniaksial sebaiknya menggunakan empat buah strain gauge pada keempat sisinya, juga dengan tambahan satu kawat keliling, dan pengujian dengan metode triaksial akan lebih menarik, karena ketiga gayanya bisa diperoleh.

\section{UCAPAN TERIMAKASIH}

Penulis mengucapkan banyak terimakasih kepada Prof. Dr. Ir. Ridho Kresna Wattimena, M.T., Prof. Dr. Ir. Irwandy Arif, M.Sc. dan Dr. Ir. Suseno Kramadibrata, M.Sc. dari Departemen Teknik Pertambangan ITB, atas segala bentuk bimbingan yang diberikan selama proses penelitian.

\section{DAFTAR PUSTAKA}

Bidgoli, M. N. and Jing, L. (2014) "Anisotropy of strength and deformability of fractured rocks," Journal of Rock Mechanics and Geotechnical Engineering, 6(2), pp. 156-164. doi: 10.1016/j.jrmge.2014.01.009.

Cheng, J., Wan, Z., Zhang, Y., Li, W., Peng, S. S. and Zhang, P. (2015) "Experimental Study on Anisotropic Strength and Deformation Behavior of a Coal Measure Shale under Room Dried and Water Saturated Conditions," Shock and Vibration, 2015, pp. 1-13. doi: 10.1155/2015/290293.

Gao, Q., Tao, J., Hu, J. and Yu, X. (Bill) (2015) "Laboratory study on the mechanical behaviors of an anisotropic shale rock," Journal of Rock Mechanics and Geotechnical Engineering, 7(2), pp. 213-219. doi: 10.1016/j.jrmge.2015.03.003.
Ismael, M. A., Imam, H. F. and El-Shayeb, Y. (2014) "A simplified approach to directly consider intact rock anisotropy in Hoek-Brown failure criterion," Journal of Rock Mechanics and Geotechnical Engineering, 6(5), pp. 486-492. doi: 10.1016/j.jrmge.2014.06.003.

Kim, H., Cho, J.-W., Song, I. and Min, K.-B. (2012) "Anisotropy of elastic moduli, P-wave velocities, and thermal conductivities of Asan Gneiss, Boryeong Shale, and Yeoncheon Schist in Korea," Engineering Geology, 147148, pp. 68-77. doi: 10.1016/j.enggeo.2012.07.015.

Min, K.-B., Kim, H. and Park, B. (2015) "Expremental and numerical anisotropic rock mechanics," in ISRM VietRock International Workshop, 12-13 March, Hanoi, Vietnam. Hanoi: International Society for Rock Mechanics, p. 11.

Rai, M. A., Kramadibrata, S. and Wattimena, R. K. (2014) Mekanika batuan. Edited by R.-R. Sundari. Bandung: Institut Teknologi Bandung.

Vervoort, A., Min, K.-B., Konietzky, H., Cho, J.-W., Debecker, B., Dinh, Q.-D., Frühwirt, T. and Tavallali, A. (2014) "Failure of transversely isotropic rock under Brazilian test conditions," International Journal of Rock Mechanics and Mining Sciences, 70, pp. 343-352.

doi: 10.1016/j.ijrmms.2014.04.006.

Wang, P., Yang, T., Xu, T., Yu, Q. and Liu, H. (2013) "A Model of Anisotropic Property of Seepage and Stress for Jointed Rock Mass," Journal of Applied Mathematics, 2013, pp. 119. doi: 10.1155/2013/420536.

Wang, X., Zhao, Y. and Lin, X. (2011) "Determination of mechanical parameters for jointed rock masses," Journal of Rock Mechanics and Geotechnical Engineering, 3(1), pp. 398-406.

doi: 10.3724/SP.J.1235.2011.00398. 